\title{
Covid-19: Macroeconomic Impacts and Policy Issues in India
}

Hiranya K. Nath ${ }^{\dagger}$

\section{Abstract}

This editorial discusses the potential short, and long-run macroeconomic impacts of Covid-19 in India, presents early evidence of some of these effects and examines policy issues that would be important in the coming days. Since the Indian economy was experiencing sluggish growth on the eve of the Covid-19 outbreak, the economic downturn could be severe, and the policy intervention would require a careful weighing of options and priorities. Given that policy space and resources are limited, policies that help manage the short-run crisis and yield significant long-run benefits should receive serious consideration.

Keywords: Covid-19; Coronavirus; Macroeconomic shock; Aggregate Demand; Aggregate Supply; Fiscal Policy; Monetary Policy; India

\footnotetext{
' Professor, Department of Economics and International Business, Sam Houston State University, Huntsville, TX 773412118 (USA); Email: eco_hkn@shsu.edu

(C) 2020 Nath. This is an Open Access article distributed under the terms of the Creative Commons Attribution License (http://creativecommons.org/licenses/by/2.0), which permits unrestricted use, distribution, and reproduction in any medium, provided the original work is properly cited.
} 


\section{Introduction}

On 31 December 2019, Wuhan Municipal Health Commission in China reported a cluster of cases of pneumonia-the first reported cases of what later came to be known as Coronavirus disease 2019 or Covid-19. In the wake of rising infection, the World Health Organization (WHO) declared it a Public Health Emergency of International Concern (PHEIC) on 30 January 2020, and a pandemic on 11 March. According to the WHO Coronavirus Disease (COVID-19) Dashboard, by the first day of summer 2020 in the northern hemisphere, that is, 21 June, more than 8.7 million people were infected by Covid-19, and about 5.3 per cent of them lost their lives. ${ }^{1}$

In India, the first confirmed case of Covid-19 infection was detected on 30 January in the state of Kerala. India began taking precautionary measures early on. For example, thermal screening of passengers arriving from China was introduced on 21 January, initially at seven airports. It was later expanded to more airports and passengers arriving from Thailand, Singapore, Hong Kong, Japan, South Korea, Nepal, Vietnam, Indonesia, and Malaysia as well. By early to mid-March, the government had drawn up plans to deal with a worsening of the pandemic in the country. On 3 March, the Indian government stopped issuing new visas and suspended previously issued visas for the nationals of Italy, Iran, South Korea, and Japan. Compulsory screening of all international passengers arriving in India was announced the next day. On 13 March, all visas, except for diplomatic and other official visas, as well as the visa-free travel for Overseas Citizens of India were suspended. Indians returning from Covid19 affected countries were asked to be quarantined for 14 days. By 16 March, all land borders with neighbouring countries were closed for passenger traffic. On 17 March, the Government of India issued an advisory, urging all Indian states to take social distancing measures as a preventive strategy for implementation till 31 March.

The government soon realised the economic fallout of all these restrictions and announced the formation of the Covid-19 Economic Response Task Force. The government also announced complete lockdown in selective districts and cities where confirmed cases were reported. On 21 March, the Prime Minister announced the first phase of nation-wide lockdown for 21 days to contain the pandemic. Later, this lockdown was extended till 3 May with conditional relaxations in areas with a lower spread from 20 April. This lockdown was further extended twice until 17 and 31 May respectively. The first phase of lockdown was successful in the sense that the doubling rate had slowed to six days from the earlier figure of three days by 6 April.

However, the prolonged lockdown led the economy to unsustainable inactivity, and the government decided to open it in a phased manner, a process christened Unlock 1 . Under this, the government divided the districts across the country into Red Zone (Hotspots with high doubling rate and a high number of active cases), Orange Zone (non-hotspots, districts with fewer cases), and Green Zone (districts with no confirmed cases or no new cases in last 21 days). Lockdown was extended till 30 June in the containment zones and activities were allowed to resume in a phased manner, starting from 8 June in other zones.

By the end of the fourth phase of nation-wide lockdown on 31 May, the total confirmed cases were 182,143 , and the total deaths were 5,164 , according to the data published by the Ministry of Health and Family Welfare. ${ }^{2}$ These numbers more than doubled to 410,461 and 13,254 in 21 days after the lockdown was over. India now

\footnotetext{
${ }^{1}$ Based on updates available at: https://covid19.who.int/?gclid=EAlalQobChMlss_qttCU6gIVOsDACh3NpgJBEAAYASAAEgKMZvD_BwE (accessed on 21 June 2020).

2 The data are available from the Ministry of Health and Family Welfare (MHFW) website: https://www.mohfw.gov.in/ (accessed on 20 June, 2020).
} 
ranks fourth in the number of confirmed cases and eighth in fatalities from Covid-19 (3.2 per cent against the world average of 5.3 per cent).

The ongoing health crisis and the resultant disruption of economic activities have had and will continue to have impacts on the Indian economy. This study discusses the potential short and long-run macroeconomic impacts of Covid-19 in India, presents early evidence of some of these effects, and examines policy issues that would be important in the coming days. Since the Indian economy was experiencing a slowdown going into the Covid19 outbreak, the economic downturn is likely to be severe, and the policy intervention would require a careful weighing of options and priorities. The study argues that given the limited policy space and resources, policies that help manage the short-run crisis and yield significant long-run benefits should receive serious consideration.

The remaining of the study is organised as follows. The next section discusses how Covid-19 fits the definition of a macroeconomic shock. A discussion on the state of the Indian economy on the eve of the Covid-19 outbreak is included in the section following this. Using a simple macroeconomic model framework, the next section discusses the potential short and longrun impacts of Covid-19 shock. It also presents fragmentary early evidence of some of the effects. The policy issues are discussed in the penultimate section. It also includes a brief discussion of the current government measures. The final section revisits the key rationale of the study and outlines concluding remarks.

\section{A Global Pandemic as a Macroeconomic Shock}

Any disturbance that has large-scale unpredictable impacts on the economy is referred to as a macroeconomic shock. Some economists argue that a shock has to be exogenous, that is, it must originate outside the economic system. ${ }^{3}$ Although a shock could be positive or negative, people pay more attention to a negative shock as it leads to undesirable economic consequences for individuals as well as societies. The outbreak of Covid-19 fits the definition of a negative macroeconomic shock.

As evidence of human to human transmission of Covid-19 surfaced, 'social distancing' became necessary to prevent the spread of potentially fatal illness caused by this novel virus. Since the three different ways of minimising the health risk from this pathogen- development of a vaccine (vaccines) to prevent its spread; development of drugs to effectively treat its infection; and people acquiring herd immunity - take time, avoiding physical proximity became the only way of handling this public health crisis in the short-run. Acting upon the opinions and advice of the scientists and public health experts, governments around the world imposed restrictive measures of various degrees, including complete lockdown to facilitate social distancing. These restrictions have disrupted economic activities with potential large-scale economic impacts.

The macroeconomic literature devotes substantial research efforts to investigate and understand the propagation of macroeconomic shocks. However, the nature of the shock (that may vary widely), the complexity of interrelations and the dynamic interactions among different agents and parts of the economic system may lead to very different outcomes. The unknown nature of a macroeconomic shock makes it hard to foresee and predict its short-run and long-run effects in a precise manner. Even the most sophisticated models have to rely on a number of assumptions, and consequently, the realisation of their predictions is predicated upon the validity of those assumptions which may or may not hold. Despite these caveats, the general macroeconomic model framework provides some insights into how the Covid-19 macroeconomic shock may play out for the Indian economy.

\footnotetext{
${ }^{3}$ For a relatively recent detailed discussion on macroeconomic shocks, how they are identified, and how they propagate, please read Ramey (2016).
} 
The State of the Indian Economy on the Eve of Covid-19 Outbreak

In order to assess the impacts of the Covid-19 shock and to consider policy measures, it is extremely important to take stock of the state of the economy on the eve of the outbreak. It is widely acknowledged that the Indian economy slowed down significantly during 2018-19.4 According to Subramanian and Felman (2019), trouble brewed as early as the immediate aftermath of the global financial crisis when export growth slowed and the infrastructure investment boom that started in the mid-2000s went sour leading to a twin balance sheet crisis involving banks and infrastructure companies. They argue that despite these problems and temporary adverse shocks of demonetisation and introduction of goods and services tax (GST), Indian economy continued to grow primarily due to the income effect of low world oil prices and the credit boom led by non-bank financial companies (NBFCs). However, the real estate bubble that resulted eventually burst in 2019. This provides a backdrop for the economic impacts of Covid-19 to play out in India and current and future policy initiatives must take cognisance of these underlying conditions. ${ }^{5}$

Let us take a look at some of the common measures used to evaluate the overall health of an economy. ${ }^{6}$ As Figure 1 shows, the annual growth rate of real GDP continuously declined since its peak in the first quarter of 2018. The real GDP increased by only 3.1 per cent in the first quarter of 2020 over the corresponding quarter of 2019. While the outbreak and the measures to prevent it in the month of March may have been partially responsible for this significant dip in the growth rate, the declining trend that started much earlier indicates serious problems elsewhere that had already been weakening the economy. This performance of the economy can be further evaluated by looking at the changes in various components on the

\footnotetext{
${ }^{4}$ There were extensive national and international media reports on India's economic slowdown during the later half of 2019 (e.g. Chakravarty 2019; Sharma 2019)

${ }^{5}$ This is different for, say, the United States. When the pandemic hit, the US economy was in very strong
}

expenditure side as well as on the production side (that is, the demand and the supply side). On the expenditure side, private consumption spending increased only by 2.7 per cent over the first quarter of 2019 and this growth is substantially lower than the growth rate of 6.6 per cent in the fourth quarter of 2019. Inventories were growing at half of a percentage as compared to a growth rate of 1.1 per cent in the previous quarter. This also indicates that firms were downsizing production in expectation of low future demand. The gross fixed capital formation fell by 6.5 per cent over 2019:Q1. This suggests a larger decline in business investment than a decline of 5.2\% in 2019:Q4. India also experienced significant decline in international trade: exports fell by 8.5 per cent and imports by 7 per cent (MOSPI 2020).

On the production side, both manufacturing and construction experienced decline: manufacturing value-added fell by 1.4 per cent over 2019:Q1 and construction by 2.2 per cent. Note that during the fourth quarter of 2019, manufacturing declined by less than one per cent and construction did not grow at all. Among the sectors that experienced growth, agriculture, forestry, and fishing grew by 5.9 per cent, and mining and quarrying grew by 5.2 per cent. Both sectors experienced some acceleration in growth. Utility services grew at 4.5 per cent compared to its decline of 0.7 per cent in the previous quarter. Among other services, trade, hotels, and transportation grew by 2.6 per cent, a decline from 4.3 per cent during 2019:Q4, and finance and real estate grew by 2.4 per cent as against its growth of 3.3 per cent during the previous quarter. Of course, public administration and defence in the government sector grew the most, by 10.1 per cent, which is slightly lower than the growth of 10.9 per cent in the previous quarter (MOSPI 2020). Obviously, manufacturing and construction were the trouble spots that are

position with historic low monthly unemployment rate of $3.6 \%$.

${ }^{6}$ Dev and Sengupta (2020) give a more detailed account of the state of the economy before Covid-19 struck. 
related to the problems we discussed at the beginning of this section.
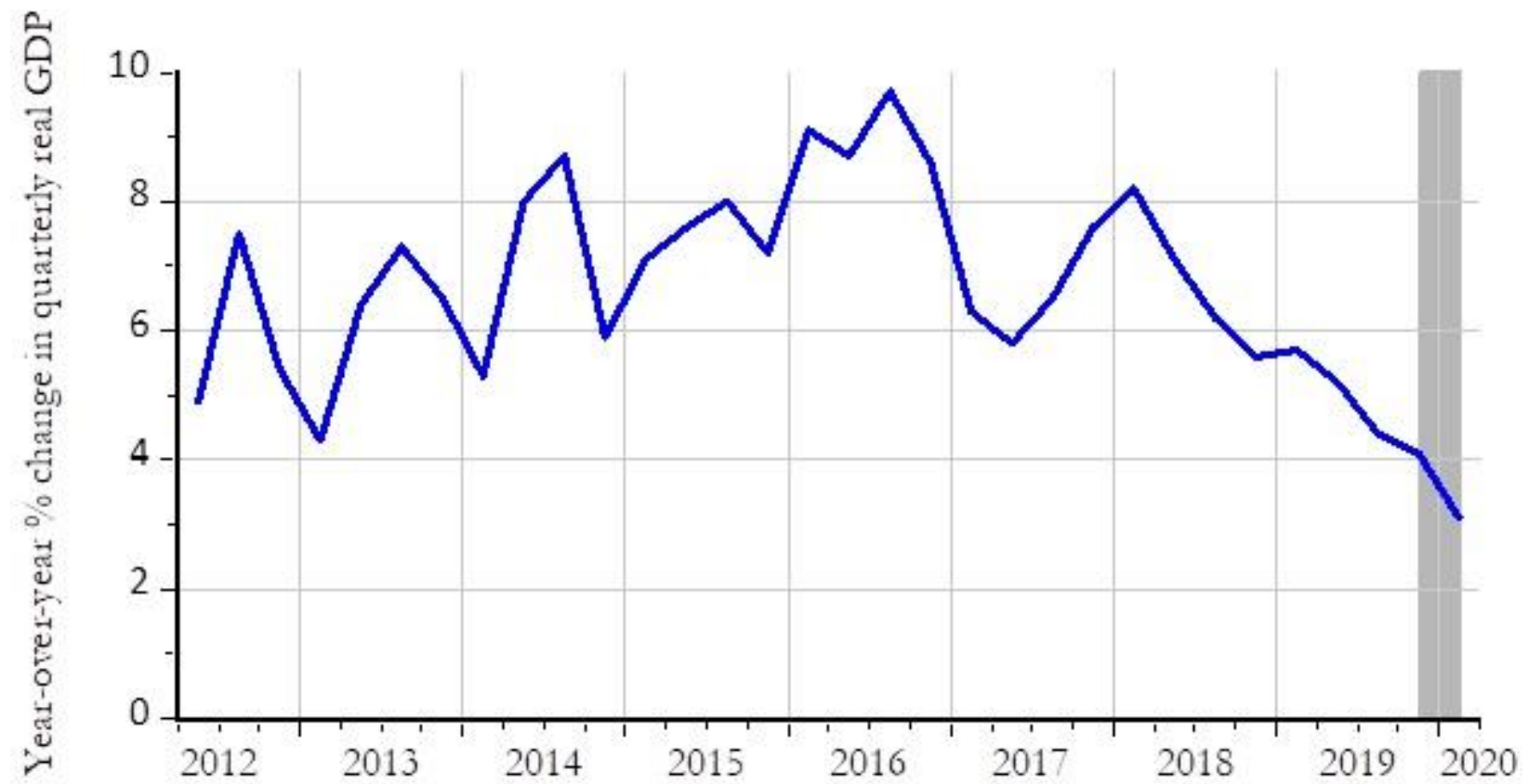

Figure 1: Annual Growth Rate of Real GDP in India: 2012:Q2 - 2020:Q1

Source: Created using data downloaded from the Ministry of Statistics and Programme Implementation, Government of India (http://mospi.nic.in/data, accessed on 20 June, 2020).

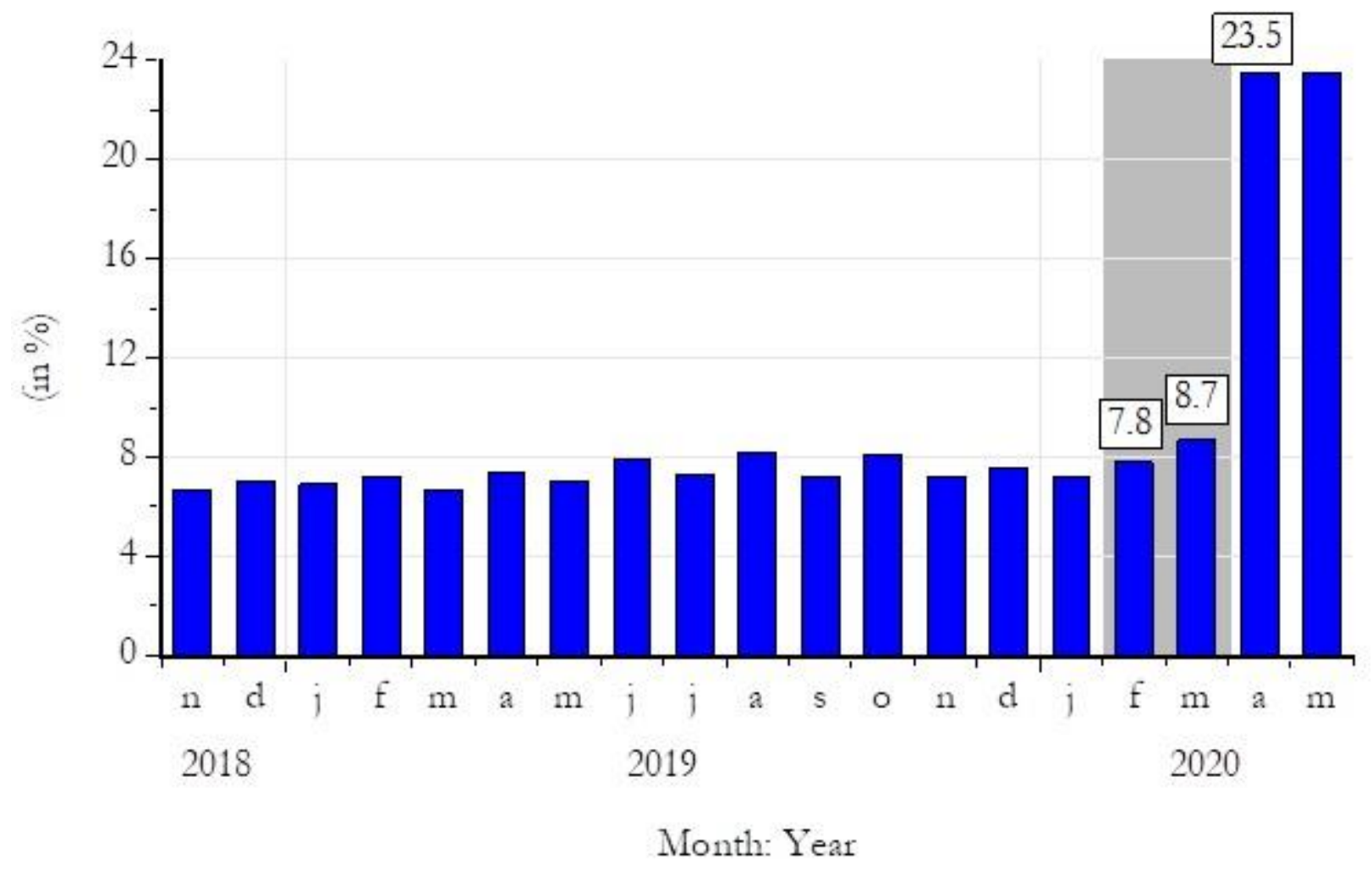

Figure 2: The Monthly Unemployment Rate in India: November 2018 - May 2020

Source: Created using the Center for Monitoring of Indian Economy (CMIE) data obtained from Trading Economics (https://tradingeconomics.com/india/unemployment-rate, accessed on 19 June, 2020). 
The decline of economic activities also implies slack labour market conditions that are often reflected in rising unemployment. According to the Center for Monitoring of Indian Economy (CMIE), the unemployment rate was on the rise prior to the pandemic. As Figure 2 shows, unemployment rate steadily increased from 7.2 per cent in January to 8.7 per cent in March 2020 and then, quite expectedly, jumped to 23.5 per cent in April and May when the entire country was under lockdown, and economic activities were severely disrupted. If the numbers of underemployment and discouraged workers are added to the number of unemployed, the labour market situation would be even grimmer.

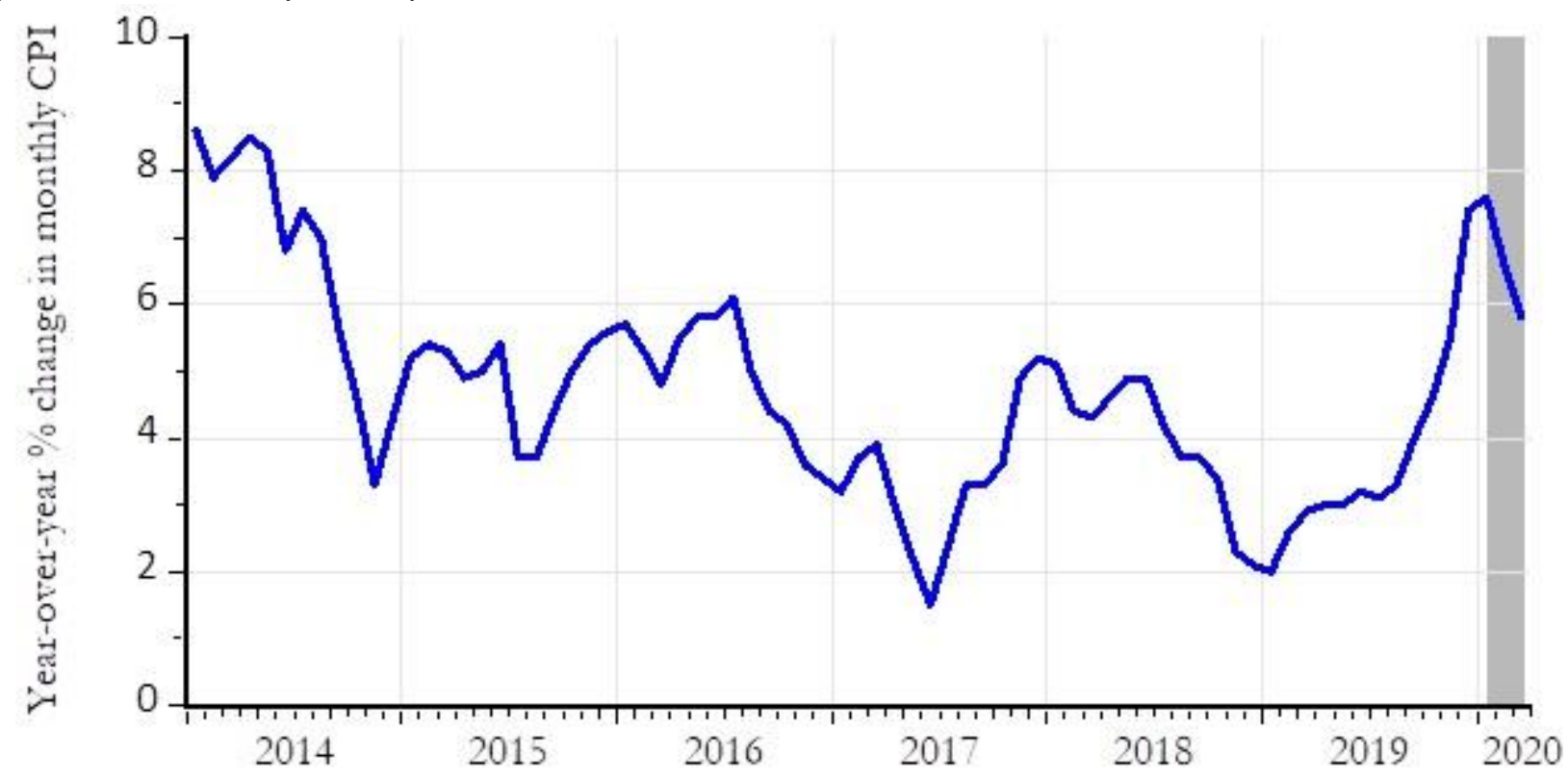

Figure 3: The Annual Rate of Inflation in India-January 2014 - March 2020

Source: Created using data downloaded from the Ministry of Statistics and Programme Implementation, Government of India (http://164.100.34.62:8080/TimeSeries_2012.aspx, accessed on 20 June, 2020)

The rate of inflation, another measure of the overall health of the economy, increased significantly during 2019. For quite some time, particularly after the adoption of inflation targeting monetary policy strategy in 2014, India's consumer price index (CPI) inflation more or less remained within the target band of $2-6$ per cent. Compared to the immediate aftermath of the global financial crisis, CPI inflation was on a downward trend as we see in Figure 3. Due to a number of push and pull factors and market imperfections, it is sometimes difficult to see what drives inflation in a country like India. However, in a crisis like the present, inflation should remain dormant so that the central bank has some flexibility to go for accommodative monetary policy. That the sharp increase in inflation has somewhat dissipated on the eve of the Covid-19 outbreak is a relief. A fall in world oil prices and an overall decline in demand may have helped this.

Some other indicators are worth looking at as we try to think about policy interventions for moderating economic impacts and recovering from the disaster that the economy is inevitably heading towards. Two such indicators are the government budget and the size of public debt. Figure 4(a) shows that government budget deficit as a percentage of GDP jumped by more than a percentage point from the fiscal year of 2018-19 to 2019-20. Increased government spending and reduced tax revenue during the last fiscal year have contributed to this significant fiscal gap. The recent budget deficit has already breached the target of 3 per cent set in the Fiscal Responsibility and Budget Management (FRBM) Act of 2003. The 
outstanding public debt as a percentage of GDP has been rising since 2014, although it has not reached the level during the global financial crisis.

By March 2019, India's non-performing loan ratio stood at 9.1 per cent, a decline from 11.2 per cent a year ago (Figure $5(a)){ }^{7}$ This ratio, an important indicator of financial sector health, reached an all-time high of 14.7 per cent in March 1999 and a record low of 2.3 per cent in March 2011. In recent years, an inadequately

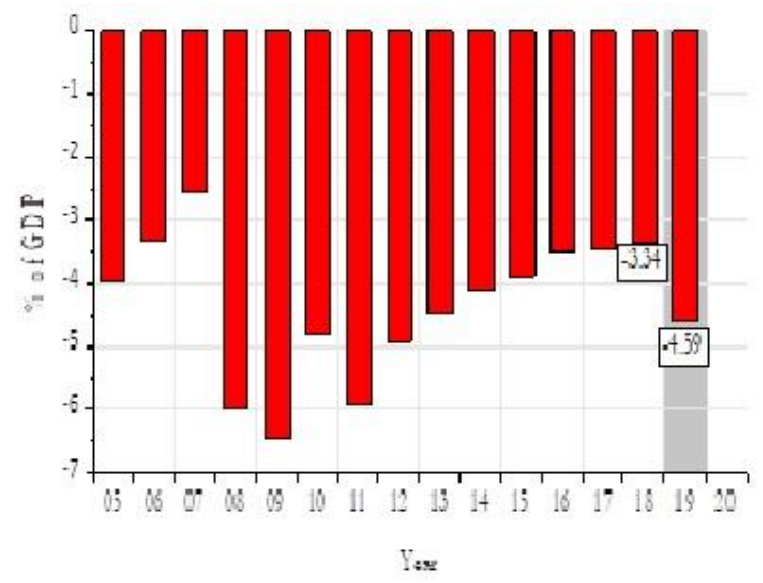

(a)Government Budget Deficit as a \% of GDP capitalised banking system has accumulated high levels of non-performing assets (NPAs), including loans creating significant risk in the financial sector. The government and RBI have initiated a number of vigilance and regulatory measures to contain this risk. However, these steps have led to risk-averse behaviour of the banks in the credit market and, consequently, commercial credit has significantly declined. In a slowing economy, this is detrimental because the economy does not receive the much-needed demand stimulus.

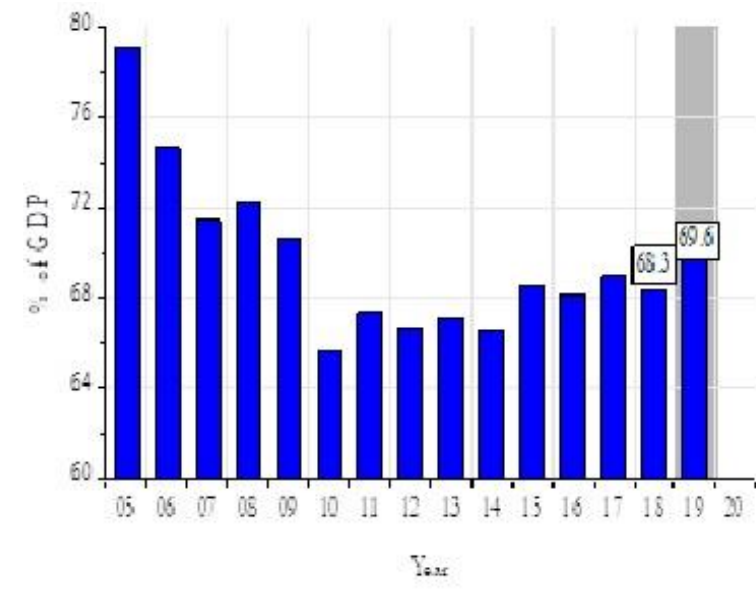

(b)Outstanding public debt as a \% of GDP Figure 4. Government Budget Deficit and Public Debt in India: 2005-06 - 2019-20 Source: Created using data obtained from Trading Economics (https://tradingeconomics.com/india/government-budget and https://tradingeconomics.com/india/government-debt-to-gdp , accessed on 19 June, 2020)

As Figure 5(b) shows, the stock market witnessed significant drop and volatility in the major indices during February and March 2020. On 23 March the SENSEX fell 4000 points (13.15\%), and NSE NIFTY fell 1150 points (12.98\%) reflecting the worst losses in history. However, the market rebounded one day after the Prime Minister announced a complete 21day lockdown on 24 March and SENSEX posted its most significant gains in 11 years, adding a value of INR (₹)4.7 trillion (US\$66 billion) for investors. In April and May, the Indian market primarily responded to the developments in the US stock market, which was by then comforted by the monetary accommodations of the Federal

\footnotetext{
${ }^{7}$ Nonperforming loans are defined as loans overdue for more than 90 days.
}

Reserve. The venture capital for start-ups fell by 50\% in 2020:Q1 from 2019:Q4

On the international front, the current account deficit as a share of GDP has been rising since 2016. However, on capital account, India has been receiving substantial foreign direct investment (FDI) even in March. The Indian rupee weakened significantly against the US dollar during March and has been relatively stable since then. The strong foreign exchange reserve position (over US\$500 billion) is definitely a strength of India's international monetary position.

Overall, the state of the Indian economy on the eve of the Covid-19 crisis was weak. It has 
increased the vulnerability of various segments of the economy and indeed increased the burden on the policymakers who will have to

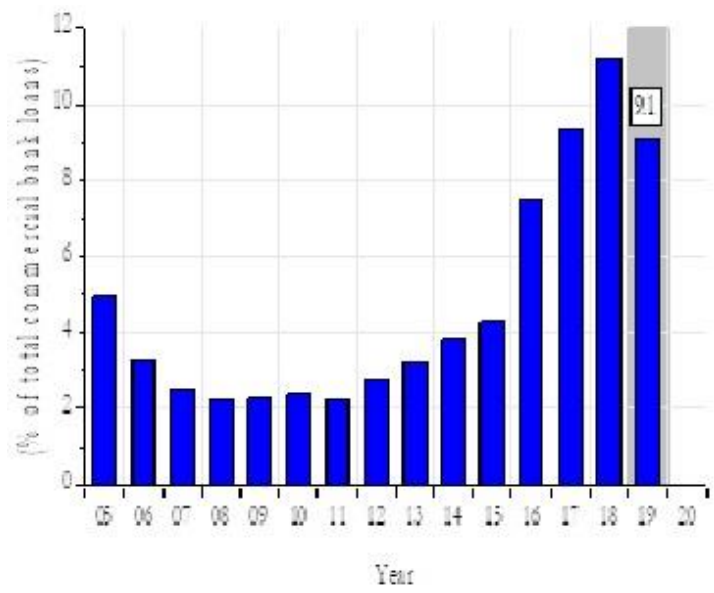

(a) Non-performing Loans Ratio tread a delicate path of careful policy making for a relatively quick recovery with minimal costs and maximum long-run benefits.

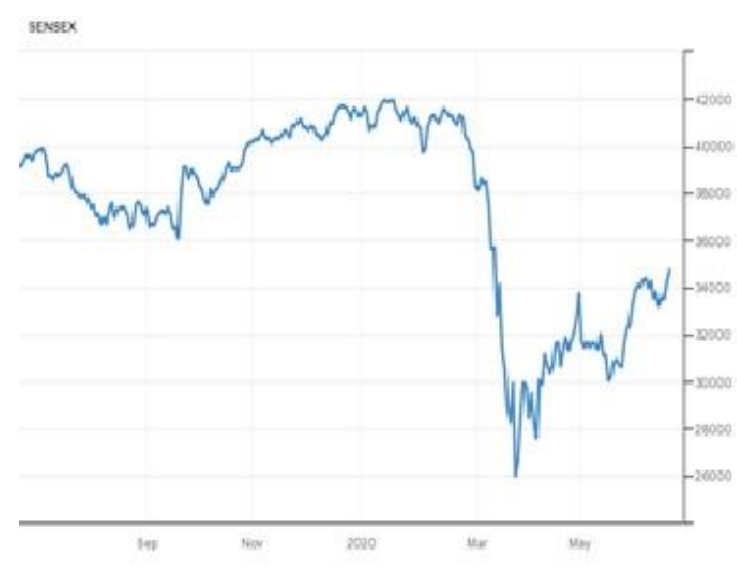

(b) Daily SENSEX Stock Index

23June, 2019 - 19June, 2020

Figure 5: Non-performing commercial bank loan ratio (2005 - 2019) and stock price Sources: (a) was created using the Reserve Bank of India data obtained from CEIC Data. (https://www.ceicdata.com/datapage/charts/ipc_india_non-performing-loansratio/?type=column\&from=1998-03-01\&to=2019-03-01\&lang=en, accessed on 19 June, 2020.) (b) was created by Trading Economics using NSE data (https://tradingeconomics.com/india/stock-market, accessed on 21 June, 2020)

Macroeconomic Impacts of the Covid-19 Shock

The outbreak of Covid-19 has led to economywide disruptions not only in India but also in most countries around the world. However, it will not be until much after this global contagion is over that we will be able to have a comprehensive assessment of the extent of damage to the economy due to this pandemic. The complexity of modern economic systems, the concurrent events - related and unrelated to the outbreak and their dynamic interactions would shape up the net effects for the economy as a whole. It is almost impossible to anticipate all that could or would happen and therefore, to have reliable predictions. Even after the episode is over, it would be difficult to clearly delineate the effects of Covid-19 from those due to confounding events. However, the macroeconomic models that we use to explain the short and long-run behaviour of the economy may provide some guidance on what we can expect from the disruptions created by the Covid-19 shock.

\section{Theoretically Plausible Effects}

\section{Short-run Effects}

Thinking in terms of the simple but widely used aggregate demand-aggregate supply model framework, we can see that this shock will affect both demand and supply side of the economy. ${ }^{8}$ Due to the restrictions, consumption has declined. New investments have not been undertaken, inventories have been used up, and international demand for goods and services produced in India has declined. Some of the government expenses may have been cut while others have been ramped up to fight the coronavirus outbreak and to provide economic viability to various stakeholders during the lockdown. Overall, it is fair to expect significant shrinkage in aggregate demand due to the pandemic.

\footnotetext{
${ }^{8}$ Any introductory level macroeconomics textbook includes an exposition of aggregate demand and aggregate supply framework.
} 
On the supply side, as production was shut down for more than two months, there has been a substantial drop in aggregate supply. Thus, one would expect a significant decline in the quantity of goods and services in the short run. That also implies that unemployment would rise. What happens to prices is not clear from this simple model framework. We can say that it would depend on the relative size of the shrinkages in aggregate demand and aggregate supply. If aggregate demand declines relatively more than does aggregate supply, prices will fall. This does not necessarily translate into a deflation, but we can expect low inflation. However, if the decline in aggregate supply is relatively larger, there may be inflationary pressure. While it is hard to anticipate which scenario will play out, it is safe to say that if the restrictions on economic activities have to be prolonged and, as a result, production does not take place or it does only partially, the second scenario is a more likely outcome.

\section{Long-run Effects}

The long-run impacts of this macroeconomic disturbance are primarily related to the disruptions in accumulation of both physical and human capital. As business investment declines, the stock of physical capital does not grow as much as it should, and it hurts long-run growth. Similarly, as the educational institutions have been closed, there has been a disruption in the process of human capital accumulation as well. The excessive stress on the healthcare system due to the fight against Covid-19 may also have a negative effect on people's health, another component of human capital. However, because of the complex interactions of several factors such as reduced pollution, increased hygiene, dangerous plights of the migrant population etc. the net impact on human capital accumulation through health outcome is nuanced and would require more careful investigation afterwards.

There are other channels through which this episode may affect the Indian economy in the long-run. Because of reduced income, some people will be using up their savings, and others

\footnotetext{
${ }^{9}$ The plight of the migrant workers has been extensively reported in the media. For example, see Pandey (2020).
}

will not be able to save as much. Overall, the total savings in the economy are likely to drop. For the overall economy, savings are essential for financing investment. Thus, the decrease in savings will also lead to lower capital accumulation which is likely to slow long-run growth.

Further, various measures to fight Covid-19 at all levels, including economic recovery efforts, will cost the governments dearly. With reduced tax earning, the government budget deficit is going to rise. As the government borrows to finance its deficit, interest rate rises, and it crowds out private investment - the diversion of private savings from the financing of private investment to that of government deficit. While a larger budget deficit may be a necessity in the short run, its persistence for a prolonged period may be harmful to the country's long-run growth.

There is another way the country's physical capital accumulation and long-run growth may be hurt. The construction of all kinds (various infrastructure projects, commercial and residential buildings) in megacities and large urban growth centres is heavily dependent on the labour of migrant workers. In the wake of the nation-wide lockdown, millions of those workers were left stranded and jobless. Media reports on their plight abound. ${ }^{9}$ Most of these workers returned to their home states. If a large portion of these workers decide not to go back immediately, the construction projects may be indefinitely delayed or permanently stalled. This will hurt long-run growth. However, a wellthought-out fiscal stimulus with increased government spending on infrastructure projects with a focus on economically backward states that also send most of the migrant workers to the growth centres - could potentially reduce the economic stress of those workers and, by improving the infrastructure, may lead to more regionally balanced growth.

The closure of educational institutions not only disrupts human capital formation but may also lead to economic inequality in the long-run. For 
many in the rural areas and from low socioeconomic background, education provided through the public education system - although not perfect - is the only way and opportunity for upward socioeconomic mobility. The psychological and economic stress created by the pandemic and lockdown may draw a full stop to the academic endeavours of a large number of such students across the country eliminating the possibility of climbing the ladder of upward mobility.

Crises also lay bare the deficiencies in a system and create opportunities for innovative thinking to mend those lacunas and for making permanent changes. In India, many parts of the socioeconomic, political, and legal system operate according to and using archaic ideology, technology, administrative and legislative procedures that are simply not appropriate for the twenty -first century. If both public and private parties take this opportunity to change at least a few things to improve public health, general education, the supply chain, and the social safety net, they may have positive longrun impacts.

\section{Early Evidence}

Since it takes a while for the data collection agencies to collect, compile, and publish data, we would not know the full extent of the shortrun economic impacts of Covid-19 in measurable quantities. With people cutting back their expenses on non-essential items, businesses stalling investment activities, and international demand being low, aggregate demand is likely to remain subdued for quite some time. Production activities have been suspended for almost three months. Consequently, by May 2020, about 140 million jobs were lost, and the unemployment rate rose to about 24 per cent. Educational institutions are closed for a prolonged period of time. The sectors that were the hardest hit due to the restrictions include transportation, travel, and tourism. Strict restrictions on all modes of transportation for an extended period of time have pushed some companies in these sectors to the verge of collapse.
March and April are the harvesting months. Due to the shortage of workers during the lockdown, some farmers could not harvest their crops, and they were wasted. According to one study, "10\% of farmers could not harvest their crop in the past month, and $60 \%$ of those who did harvest reported a yield loss". ${ }^{10}$ India's food supply chain is heavily dependent on manual workers. The imposition of social distancing norms and lockdown severely disrupted and created stress for the supply chain.

There has been a significant decline in India's fuel demand. According to an International Energy Agency report, India's fuel consumption will decline by 5.6 per cent in 2020 . There has been an increase in the demand for cooking gas, spurred partly by the provision of three months of free liquefied petroleum gas (LPG) for below poverty line (BPL) families announced as a part of the assistance package during the lockdown. According to a report, the demand increased by 20 per cent in the month of April (Bhaskar 2020).

The stock market has been responding to the messages that have been discerned from domestic as well as international events, including the unfolding of the outbreak and its toll on human life. The volatility of the market indicates noises and a lack of clarity in the system. India's sovereign credit rating has been downgraded by most major rating agencies. Although this may adversely affect India's ability to borrow in the international market, the fact that most countries are in similar situations it is ultimately how India manages the crisis in next few months and years will determine its standing in the international debt and capital market.

State governments have suspended capital works and cut spending on developmental schemes. Some state governments had to cut the salaries of their employees. With little revenue coming in, the state governments are likely to face tremendous financial stress. Differences in the fiscal health of the states and their policy responses may widen regional disparities. However, prudent policy choices by

\footnotetext{
${ }^{10}$ Reported by Christi (2020) in The Indian Express.
} 
states on the lower spectrum of development distribution may also help them bridge the gaps.

There have been some positive developments due to nation-wide lockdown as well. For example, there have been reports that air pollution has gone down significantly in megacities like Delhi (see, for example, Slater 2020). Similarly, due to restrictions on road travel and transportation, traffic accidents and road fatalities have decreased substantially (Wallen 2020). Of course, travel, transportation and other economic activities have now resumed slowly, and it is hard to predict how long these positive effects last.

As we see, there is fragmentary evidence of the effects of the Covid-19 outbreak. As the data becomes available, we will have a more comprehensive picture of the macroeconomic impacts.

\section{Policy Issues}

Starting on 21 March, the Government of India and state governments announced and implemented various financial and economic assistance programs for targeted sectors or groups: the health sector, the poor, the farmers, the unorganised as well as the organised sector, and the state governments. These packages were to provide funds for infrastructure building, support to stressed businesses, direct cash transfer, and collateral-free loans. Some state governments announced their own assistance programmes. ${ }^{11}$ The Reserve Bank of India (RBI), through its monetary policy and other crisis management tools, tried to mitigate the financial and monetary system stresses. Among the measures the central bank announced, it reduced the repo and reverse repo rates and provided liquidity of INR ( $₹$ ) 3.74 trillion (US\$52 billion) to the financial system. In order to relieve fiscal stress of the state governments, RBI announced ways and means advances (WMA) and other short-term liquidity to those governments. It relaxed repatriation limits to exporters, provided special finance to the National Bank for Agriculture and Rural

\footnotetext{
${ }^{11}$ Dev and Sengupta (2020) presents a critical appraisal of these measures pointing out to several inadequacies.
}

Development (NABARD), Small Industries Development Bank of India (SIDBI), National Housing Bank (NHB), and Export and Import (EXIM) Bank to help the respective sectors these banks serve. To provide relief to the borrowers at the time of reduced income, RBI put equated monthly instalments (EMIs) on hold for three months. The overarching goal of these targeted programs was to provide short-term relief and to reduce stress among the groups that are perceived to be most vulnerable in the wake of the considerable uncertainty brought upon them by this unexpected event.

On 12 May, the Prime Minister announced a INR (₹) 20 trillion (US\$280 billion) stimulus package, equivalent to $10 \%$ of India's GDP. This includes the previous government packages as well as the total liquidity of INR (₹) 8 trillion provided by RBI, which accounted for about $40 \%$ of the package. The Prime Minister articulated a vision of Atmanirbhar Bharat (Self-reliant India) with a focus on increasing domestic production, taking advantage of the opportunity created by the coronavirus crisis.

The economy has undoubtedly suffered a tremendous setback during more than two months of nation-wide lockdown under four phases. As the economy reopens under Unlock 1 , the number of cases is also on the rise. It is unlikely that all economic activities will resume to their full capacity soon. With no vaccine yet in sight and no definitive cure, the unknown and uncertainty about the health risk of the virus will linger for a while. It will undoubtedly affect economic agents' financial and economic decision- making ability with consequences for short and long-run evolution of the economy.

Broadly, the goals of any fiscal and monetary policy intervention would be (i) to get the economy out of the woods, that is, to manage the short-run crisis, and (ii) to take it back to the sustained growth path. To achieve these goals, these interventions should: 
- provide for the necessary means to fight the pandemic and minimise the loss of life

- provide for the most vulnerable sections of the society

- help agriculture and allied activities; and micro, small, and medium enterprises (MSME) get through the crisis. Given that these sectors are vital for employment generation and also more vulnerable, providing help to weather the storm should be a priority

- make sure that the well-behaved large enterprises can get through the crisis

- ensure monetary and financial stability by providing liquidity and incentives to the banks so that they get the money out in the system. The current risk aversion of the banks in the wake of increased regulation and vigilance put $\mathrm{RBI}$ in a tough spot as the central bank has to choose between relaxing regulation and losing the effectiveness of monetary policy in providing liquidity to the financial and economic system

- ensure financial sustainability of the state and local governments

- send clear signals to the potential international lenders that although the country may have to give up the fiscal discipline to manage the crisis in the short-run, it will regain its fiscal order rather quickly. It may be challenging to convince them as India's recent record has not been up to the mark.

Given the extent of the potential damages to the economy, it will be costly. However, the policymakers need to recognise that resources are extremely scarce. First, the government revenue earnings from tax and public sector enterprises have declined and, given the disruptions to the economy, they will decline even further. Second, there are limits to borrowing. Because of the pervasive nature of the crisis, private savings are down, and this may be limiting how much the government can borrow. It is important to note that the household saving rate (household saving as a percentage of GDP) has been declining over the years. According to the $\mathrm{RBI}$, this rate declined from 23.6 per cent in 2011-12 to 18.2 per cent in 2018-19 (RBI 2020, p. 36). Furthermore, this pandemic has affected most economies around the world, thus reducing the available funds for borrowing internationally. This may be further restricted by the downgrading of India's sovereign credit rating. Finally, the Covid-19 pandemic has hit the US and other advanced economies really hard. With their economies in crises - and also given the current geopolitical situation - it is unlikely that there will be significant external help. As discussed before, the risk-aversion of the commercial banks in response to the government (RBI) regulations in recent years may also have restricted the policy space.

Given these limitations, the policymakers need to consider the tradeoffs carefully and make prudent choices. In particular, they should give serious thoughts to options that combine shortrun crisis management goal with long-run benefits to the economy.

\section{Conclusion}

As the Covid-19 outbreak unfolds in India and across the globe, the economy continues to suffer. We would not know the full extent of the damage until much after the pandemic is over. The duration of the outbreak, the restrictive and preventive measures, together with a whole host of other factors, will determine the overall impact. It is almost certain that it will take India to a deep recession with a significant decline in gross domestic product and very high unemployment. How the impacts play out in the long run will depend on the changes people and businesses make and the policy responses of the government. Given the limited nature of available resources and other limitations, the policymakers in India have to carefully weigh the policy options and choose those that have the largest payoffs in the short as well as long-run.

\section{References}

Bhaskar, U. (2020, 22 April ). Domestic cooking gas demand spikes in April during lockdown.

livemint. (https://www.livemint.com/industry/energy/in 
dia-s-domestic-cooking-gas-demand-spikes-inapril-during-lockdown-11587483472044.html, accessed on 21 June 2020)

Chakravarty, P. (2019, 27 August). Viewpoint: How serious is India's economic slowdown? $B B C$ News. (https://www.bbc.com/news/world-asiaindia-49470466, accessed on 21 June 2020)

Chishti, Seema (2020, 22 May). “New Research: How lockdown has impacted Indian farmers, their yields". The Indian Express.

(https://indianexpress.com/article/explained/h ow-coronavirus-lockdown-has-impacted-indianfarmers-their-yields-6421569/, accessed on 21 June 2020)

Dev, S. M. and Sengupta, R. (2020). Covid-19: Impact on the Indian Economy Working Paper WP-2020-013. Mumbai (India): Indira Gandhi Institute of Development Research, Mumbai.

MOSPI (2020). National Accounts Data, Ministry of Statistics and Programme Implementation Website. (http://www.mospi.gov.in/data, accessed on 19 June 2020)

Pandey, G. (2020, 22 April ) Coronavirus in India: Desperate migrant workers trapped in lockdown. BBC News.

(https://www.bbc.com/news/world-asia-india52360757, accessed on 21 June 2020)

Ramey, V.A. (2016). Macroeconomic Shocks and Their Propagation. In Taylor, J. B. and Uhlig, $\mathrm{H}$. (eds.) Handbook of Macroeconomics, Vol. 2, Ch. 2, 71-162. New York: Elsevier.

RBI (2020). Monetary Policy Report, April 2020. Mumbai: Reserve Bank of India.

(https://rbidocs.rbi.org.in/rdocs/Publications/P DFs/MPRAPRIL2020E3D4AD8245734F27B6C568 8F22B4FA2F.PDF, accessed on 21 June 2020)

Sharma, S.N. (2019, 1 December). Severe slowdown: When will the Indian economy recover and how? The Economic Times.

(https://economictimes.indiatimes.com/news/e conomy/indicators/severe-slowdown-whenwill-the-indian-economy-recover-andhow/printarticle/72310684.cms, accessed on 21 June 2020)

Slater, J. (2020, 11 April) In India, life under coronavirus brings blue skies and clean air. The Washington Post.

(https://www.washingtonpost.com/world/asia_ pacific/india-coronavirus-delhi-clean-airpollution/2020/04/10/ac23dd1e-783e-11eaa311-adb1344719a9_story.html, accessed on 21 June 2020)

Subramanian, A. and Felman, J. (2019). India's Great Slowdown: What Happened? What's the Way Out? CID Faculty Working Paper No. 370. Cambridge, MA: The Center for International Development at Harvard University.

Wallen, J. (2020, 1 May). Overall fatalities in India drop despite coronavirus outbreak. The Telegraph.

(https://www.telegraph.co.uk/news/2020/05/0 1/overall-fatalities-india-drop-despitecoronavirus-outbreak/, accessed on 21 June 2020)

\section{Acknowledgements}

This article is partially based on my webinar presentation at the Two-Day Online Workshop on Impact of COVID-19 on Indian Economy with Special Reference to Assam organized by the Department of Economics, Bodoland University, Kokrajhar, India, on June 6-7, 2020. I would like to thank Professor Manjit Das, Dr. Sijousa Basumatary, and the participants for their questions and comments. The usual disclaimer applies. 